\title{
Micro Housing: Typological study and implementation in Malaysia
}

\author{
Mohd Fairus Kholid, Puteri Mayang Bahjah Zaharin \\ Centre of Studies for Architecture, Fakulti Senibina, Perancangan dan Ukur (FSPU), Kompleks Alam Bina dan Seni Reka, \\ Universiti Teknologi MARA (UiTM), Kampus Puncak Alam, 42300, Bandar Puncak Alam, \\ Selangor, Malaysia \\ firusfairus@gmail.com, bahjah55@gmail.com \\ Tel: $+6019-4785075$
}

\begin{abstract}
The micro-housing project introduced by Kuala Lumpur City Council (DBKL) has received cynical rumours amongst the B40 income group due to its impracticality, thus suggesting that micro-housing standard is misinterpreted and simplified. As such, this paper intends to investigate the potentiality of ideal micro-housing that is suitable for the Malaysian context, specifically for the B40 community. Based on a bottom-up approach, this research divides into the micro and macro study. In the micro-study, the focus is specifically on the typological design of micro-housing. Hence this leads to a macro context, which developed the typological analysis in regards to the regional cultural influence. In thoroughly, from seven (7) international precedents, micro-housing can be formulated into four main typologies that include Box, Mobile, Machine, and Props type. These typologies incline towards two (2) cultural domains, namely Possession Domesticity, which demonstrates Westerners influence through technological advancement and Transience Domesticity that portrays Orientalist influenced by the mixture of practicality and human psychology. These attributes tested in three (3) local microhousing projects that consist of two prototypes by local architect and a built micro-housing project by DBKL. The result shows that both prototypes are potentially ideal. However, DBKL's built project demonstrated a minimal standard of appropriate micro-housing living. It founds that the lack of axiological human needs may lead to a degradation of values and behaviour. Thus, it significantly recommends that the projects reconsider of adapting the psychological needs for the betterment of its user's living.
\end{abstract}

Keywords: micro-living, adaptable housing typology, regional cultural study, psychological needs

eISSN: 2398-4287 @ 2019. The Authors. Published for AMER ABRA cE-Bs by e-International Publishing House, Ltd., UK. This is an open access article under the CC BYNC-ND license (http://creativecommons.org/licenses/by-nc-nd/4.0). Peer-review under responsibility of AMER (Association of Malaysian Environment-Behaviour Researchers), ABRA (Association of Behavioural Researchers on Asians) and cE-Bs (Centre for Environment-Behaviour Studies), Faculty of Architecture, Planning \& Surveying, Universiti Teknologi MARA, Malaysia.

DOI: https://doi.org/10.21834/e-bpj.v4i12.1934

\subsection{Introduction}

Issues on the rise of housing prices, deficiency of affordable housing (Edgeprop, 2018), and deserted downtown (Tan.M,2018) have been lately showering the city of Kuala Lumpur. The impact falls on the increasing cost of living, where citizens are forced to live in suburban areas to seek an affordable living. This strategy is a waste due to the expenditure and time spend on daily commuting. While everyone is adapting with an economic saving plan, the B40 group is facing the most significant burden. Their livelihood has been at stake as 'good life' is beyond their reach, and the National B40 Action Plan (UNDP, 2016) is becoming an urgency.

The call for a decent living has been part of the World Urban Forum (WUF9) 2018 strategy held in Kuala Lumpur. In collaboration with Think City, Kuala Lumpur City Council (DBKL) has initiated a think tank forum to propose a new living in the city. The solution is dynamic; a micro home for downtown Kuala Lumpur. This agenda aims to provide an affordable scheme for young generations right in the middle of the city where work is within walking distance, hence, eliminating the dependency on private transport. The scheme also promotes an ideal urban community living with proper public transportation service and urban design and planning strategy.

eISSN: 2398-4287 @ 2019. The Authors. Published for AMER ABRA cE-Bs by e-International Publishing House, Ltd., UK. This is an open access article under the CC BYNC-ND license (http://creativecommons.org/licenses/by-nc-nd/4.0). Peer-review under responsibility of AMER (Association of Malaysian Environment-Behaviour Researchers), ABRA (Association of Behavioural Researchers on Asians) and cE-Bs (Centre for Environment-Behaviour Studies), Faculty of Architecture, Planning \& Surveying, Universiti Teknologi MARA, Malaysia. DOI: https://doi.org/10.21834/e-bpj.v4i12.1934 
Two prototypes are selected; The 'Urban Micro Village' by Tetawowe Atelier and AMC architect (Tetawowe, 2018) and 'Microhouse' by Studio Bikin (Studiobikin, 2018). The 'Urban Micro Village' is designed to fit into two standard car parking lots. The scheme emphasized on kongsi area at the ground level where the community living flourished. Meanwhile, the 'Microhouse' focused on vertical development with an innovative marketing strategy. Both prototypes demonstrated the different approaches of micro-living, adapting the global idea into the local market, and thus, attracting high positive responses.

In early 2019, DBKL launched a new micro-housing project known as the 'Perumahan Bandar Jalan TAR'. Located in the heart of downtown Kuala Lumpur at Jalan Tuanku Abdul Rahman (TAR), this project acts as a temporary housing solution for the B40 working adults who are looking for living quarters as a startup of their city career. The proposal aspired to reduce the initial living burden by providing an ample buffer period for the youngsters to accumulate a certain amount of capital towards the betterment of their future. Although the proposal meant for a good cause, it received cynical criticisms. The idea of 'capsule hotel' circulated by DBKL is seen to be temporary and is defeating the housing term. Furthermore, the sharing condition of 4 to 6 persons in one room might act as a 'City Hostel.' These scenarios suggest the misinterpretation and simplification of the micro-housing concept beyond the parameters of local prototypes built during the recent World Urban Forum.

As such, this paper intends to investigate the potentiality of ideal micro-housing that is suitable for the Malaysian environment, specifically for the B40 community. Consequently, the objective of this paper is as follows:

1) to identify the function and affordability of micro-housing as an alternative for urban living.

2) to analyze the practice of micro-housing through regional cultural context and typological study.

3) to determine the ideal design factors of micro-housing for the B40 community in Kuala Lumpur.

\subsection{Literature Review}

\subsection{Definition}

Micro housing is a game-changer in the housing industry. Its existence corresponds to several changing factors, particularly the demographic trends, space limitation, and living costs (Resourcefurniture, 2018). There is no particular definition of what microhousing is. However, a full description provided by the Urban Land Institute (ULI) Report identified micro-housing as a purpose-built unit, typically urban, small studio or one-bedroom using an efficient design that appears more substantial than it is. The size ranges from 280sqft to 450sqft (ULI, 2014). This definition justified the attributes of micro-housing, which in size is considerably $20 \%$ to $30 \%$ smaller than the conventional unit.

\subsection{Current Market Performance and Market Acceptance}

\subsubsection{Market Performance}

From the perspective of market performance, the trend of smaller units has changed in recent years by the shift of the unit typology. Unlike the average conventional housing where size and area of the unit decreases, the current trends lean more towards a smaller studio or one-bedroom apartment. This condition is due to the demand for high-density neighbourhoods created in new suburban areas. Based on the data obtained by the Urban Land Institute (2014), units less than 600sqft has higher occupancy value as compared to other conventional properties.

\subsubsection{Consumer Research}

Micro-homes are seen most in urban areas. Although the units are limited in space, it has attracted a great deal of attention due to its strategic location, which is surrounded by the excellent provision of infrastructure and amenities such as grocery stores, restaurants, gymnasium, and laundry. Single persons also prefer micro-homes as it allows one to live independently. While many first time consumers are sceptical of living in small units, this perception seemed to change once they have occupied the space. Instead, the satisfaction level proved to be similar to conventional housing. Despite these positive impacts, people often perceived micro-homes as temporary living. Most tenants in the United States have a lower likelihood of renewing their rental (most of the micro-housing in the United States are rentable) when their family and income expanded. This fact is due to more space is needed to satisfy their needs. Furthermore, it demonstrates the inefficiency of unit planning (ULI, 2014).I

\subsubsection{Lifestyle Living}

Micro-homes have evolved to become more trendy and full of lifestyle. It has attracted many, particularly the millennial due to its lower rental rate and simple and creative living. The millennial is known to be typically mobile and is opportunity centric. They avoid hassle and opt for ready to move-in property (Lake.R, 2019). Being a natural influencer, the millennial generate new interest in 'urbanizing authentic' location (ULI, 2014). These characteristics promote the rebranding of micro-housing towards a lifestyle living, thus, influence the target market audience.

Lifestyle in the living context is defined as a composite of motivation, needs, and wants of individuals influenced by cultural, family, reference groups, and social class factors (A.G. Sarip, 2015). According to Wentling (1995), rather than just providing shelter, small housing has transcended itself, giving provisions towards lifestyle-oriented environments. New branding such as Innovation Units, Nano Units, LaunchPad, Eco-Friendly Unit, and Lifestyle Unit are gradually replacing the notions of 'micro' house, which has previously reflected with negative connotations. In parallel to its new branding, the design for micro-living has creatively developed into several 
innovative schemes such as convertible furniture with decent storage, large volume, oversize operable window, linear practical kitchen, and extensive landscape outdoor space (ULI, 2014).

\subsection{Cultural and Regional Context}

\subsubsection{Single Space Living}

The concept of micro-living is not relatively new. The advent of single space living has long-established with provision given to basic amenities to accommodate a single living needs. The initial design of living was as a single circular space, which later transformed into a rectangular shape due to its practicality in terms of function and constructional detail. The plan later evolved into a more elaborate plan that transpired the single space into collective space with spatial quality becomes an appealing order that governed a particular typological identity (G. Stephen, 1974, 2002).

Technological advancement has significantly influenced the typology of living. The introduction of prefabricated modular objects allows the functions and activities of space to be modified and downsized. The concerns of sustainability also influenced designers to rethink space. Instead of seeing it as a complex system, space is made simple and flexible, hence, dominating the culture in the form of microliving.

\subsubsection{The Aesthetic of Abundance}

Micro housing is a microcosm of living. It ventures into the micro notion of home, which often focuses on the way people experience and understand their environment (P.Elia, 2001). It posited as a key in transmitting and codifying an image of oneself to others through appropriate material embodiment. The idea of images and experience in micro-housing has very much rooted in the American consumerstyle and culture (P.Dobers, L.Strannegard, 2005). Here, micro-housing is seen as an agent to propagate the idea of 'aestheticization' where the individuality of design signifies a crucial part of living.

In the context of micro-housing, material and object possession becomes the main feature of a space. The aesthetic of abundance embedded in every interior design, including spatial quality, fittings, and fixtures intend to enhance newness and satisfaction among the users. Innovative design ideas and new-sophisticated tools and objects help to optimize and influence the functions and activities of the space.

\subsubsection{Zen Harmony}

In the context of orientalist, the possession of scarce material becomes the subject of micro-housing. It focuses on the man's central position, where materiality revolves around him (G.Stephen, 2002). The domesticity of living forms a perfect setting, frank and straight forward construction, pure form, no striving for picturesque effect, and no overloading of unnecessary decorations and furnishings. The void of abundance creates an intimate, humane interaction that reflects the social organization (D. Maria, 2001). These conditions resemble the embodiment of Zen harmony (D. Maria, 2001), where material culture becomes transience and less permanence, hence, evoking the sense of self-actualization (G.Pauline, 2001). The void is an essential element in the orientalist micro-housing. The house conceived as a stage with the support of objects. It also promotes the adaptation of living through a single shifting plane that can transform a single space into dual or multiple modes of functions.

\subsubsection{The Psychological Needs of Living}

Physical surroundings can profoundly influence the psychological aspects of the individuals and give a strong perception of space. The Max Neef Model of Human Scale Development defined human needs into two (2) categories that are existential and axiological needs. The existential human needs focused on the needs of Being, Having, Doing, and Interacting. In contrast, the axiological human needs emphasized the needs of Subsistence, Protection, Affection, Understanding, Participation, Creation, Leisure, Identity, and Freedom. In Maslow's Hierarchy of Needs, human needs are categorized into pyramid hierarchy, starting with the physiological needs, followed by safety, love, belonging, esteem, and self-actualization.

\subsection{Methodology}

\subsection{Qualitative Ethnographic Study}

Based on a qualitative ethnographic study, the research emphasized on the contextualization of micro-housing through design, functionality, and regional culture. There are two parameters to be examined; (1) micro study which focused on content analysis and (2) macro study through thematic analysis. As the synthesizing process is a concern, this study is conducted using the bottom-up approach, where micro analysis becomes the basis for the macro study.

\subsection{Micro Study: Content Analysis}

In the micro-study of content analysis, the design approach and concept are regulated through selected precedent studies from local and international projects. The local precedents are the completed micro-housing project developed by DBKL known as the Perumahan Bandar Jalan TAR, and two award-winning micro-housing prototypes exhibited in the Ninth World Urban Forum held in Kuala Lumpur 
in 2018. The international precedents are selected based on highly published and completed projects with seven (7) existing projects gathered from all around the world.

\subsection{Macro Study: Thematic Analysis}

Data development from the micro-study of content analysis forms the parameters for the thematic analysis. In this macro study, initial data are decoded to identify broad themes and patterns related to cultural and regional evidence of micro-housing. The findings obtained from this analysis are then compared with the local and international approaches of micro-living.

\subsection{Limitation of Study}

There are no specific guidelines that define the exact typology of micro-housing. The study of spatial layout for each micro-homes is based on the existing micro-housing from all over the world. They are built and widely published in magazines and journals. Also, further exploration of the effectiveness of micro-housing in local context could not be made as there is no local precedence to support this claim.

\subsection{Findings}

Data from Table 1 shows three (3) examples of micro-housing in Malaysia. The first two are prototypes developed by the local architects. The final example is a recent micro-housing project built by DBKL at Jalan Tuanku Abdul Rahman, which is now under its promotional phase. Each prototype highlights different approaches towards micro-housing with prototype 1,2, and 3 emphasize the space, objects, and partition, respectively, to define its functions and activities.

Table 2 demonstrates the strategies for micro-living taken from seven (7) samplings of the existing micro-homes from the United States, Europe, and the Asian continent. Based on the findings, each of the micro-homes has an average floor area of 200 sqft to 450 sqft. Each unit also provides different contents, intentions, and aims for micro-living.

Data in table 2 are then investigated in table 3 to determine the correlation between the typological context of micro-housing and its regional cultural stems. Four (4) typological themes identified; Box, Mobile, Machines, and Prop type. The themes are categorized based on the attributes of the object, compatibility, system, and environmental factor. These attributes displayed an inclination to two (2) most canonical cultural influences, namely Possession and Transience Domesticity. The Possession Domesticity represents the westerners' approach, while the Transience Domesticity signifies the orientalist approach. A similar context, the micro cube and micro window house possess similarities with the orientalist approach while other micro-housing types seemed to lean towards the westerner approach.

\subsection{Discussion}

\subsection{Local Micro Housing Approach and Typological Study Similarity}

Based on table 4, the typological domain for prototype 1 possesses strong similarities with the Prop Type. With emphasis given to the volumetric of space, prototype 1, focuses on creating volume and void. It creates a duality of space that provides segregation between the private or a confined sleeping area located on the upper level and semi-private or semi-confined indoor communal area at the ground level, which opens out to the outdoor communal area known as kongsi. Concerns are also given to the maximization of light, air, and view through large openings, which is similar to the micro cube and micro window house. The approach for prototype 1 , is highly influenced by the orientalist with functions and activities defined by the spatial layout.

In prototype 2, the insertion of objects or prefabricated modular furniture with skeletal shells as the framework for the micro house demarcates the boundary of micro-living. The concept possesses profound similarities with the Machine Type as space is made flexible and maximized through prefabricated objects that can fold, move, expand, elevate, and convert into various sets of functions. The spatial layout opens out to a large outdoor communal area. The design also allows stacking and overlapping of units to create a compact vertical village. Unlike prototype 1 , prototype 2 , highly links to the westerner approach whereby the objects possessed by the users define the functions and activities of space.

The approach in prototype 3 , is relatively different from the existing typological domains of micro-housing. The only similarity seen but in a very minimal way is the prefabricated modular wardrobe. Unlike prototype 2, this object does not signify function as a whole, but it is merely an object within a space that accommodates the need of the user. The demarcation of space is through partitions that create a cubicle or a unit. The concept for prototype 3, resembles the Capsule Hotel, where it only provides sleeping and bathing facilities. The prototype 3 , could correspond to the Box Type through modification of objects into a compact package of prefabricated modular furniture.

\subsection{The Influence of Psychological Needs of Living in the Local Micro-Housing}

Prototype 1 to 3 categorized the concerns of the psychological needs of living into two (2) categories; human needs into concerns that include personal space, privacy, withdrawal and territoriality, and spatial behaviour, which consists of spatial adaptation, crowding, and influence of space. The human needs into concerns engage with the fundamental aspects of needs for living while the spatial behaviour involves the values of living. These categorizations of needs are cross-checked with the Max Neef Model and Maslow Hierarchy of Needs. 
Table 1: Comparison between local World Urban Forum prototypes and Perumahan Bandar Jalan TAR by DBKL

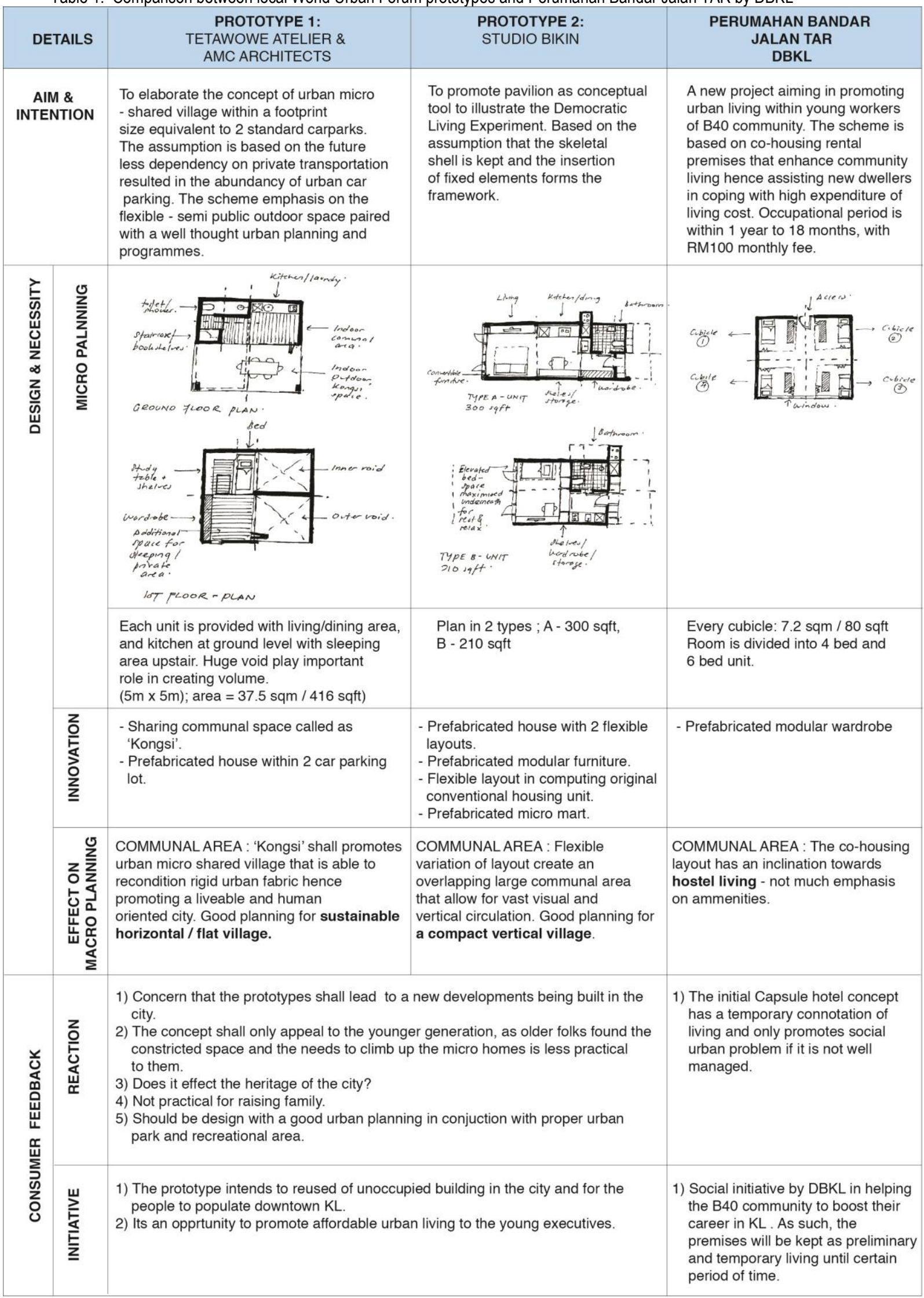

Source: Author 
Table 2: A precedent study on micro-housing in a different region

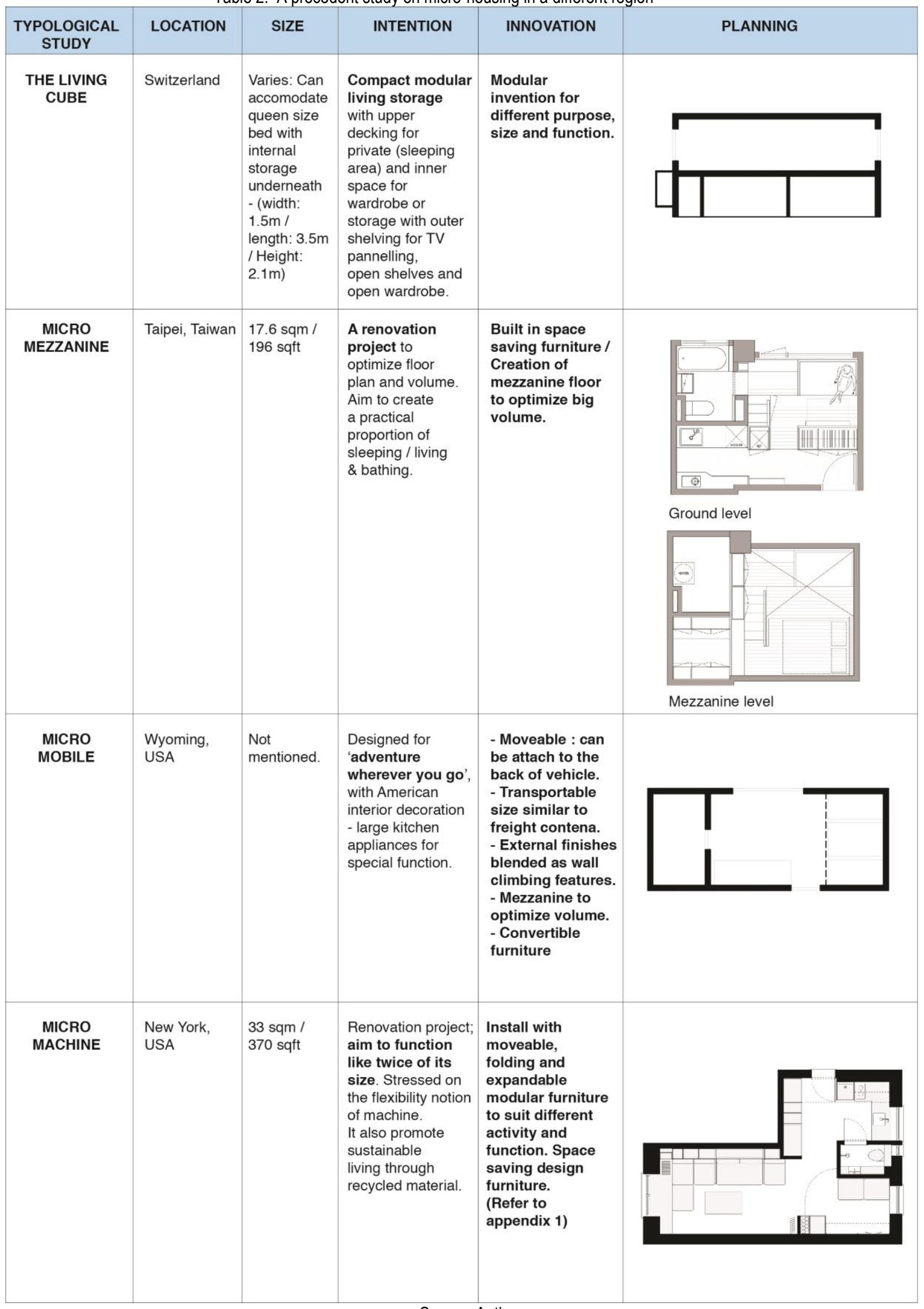


Table 2: A precedent study on micro-housing in a different region

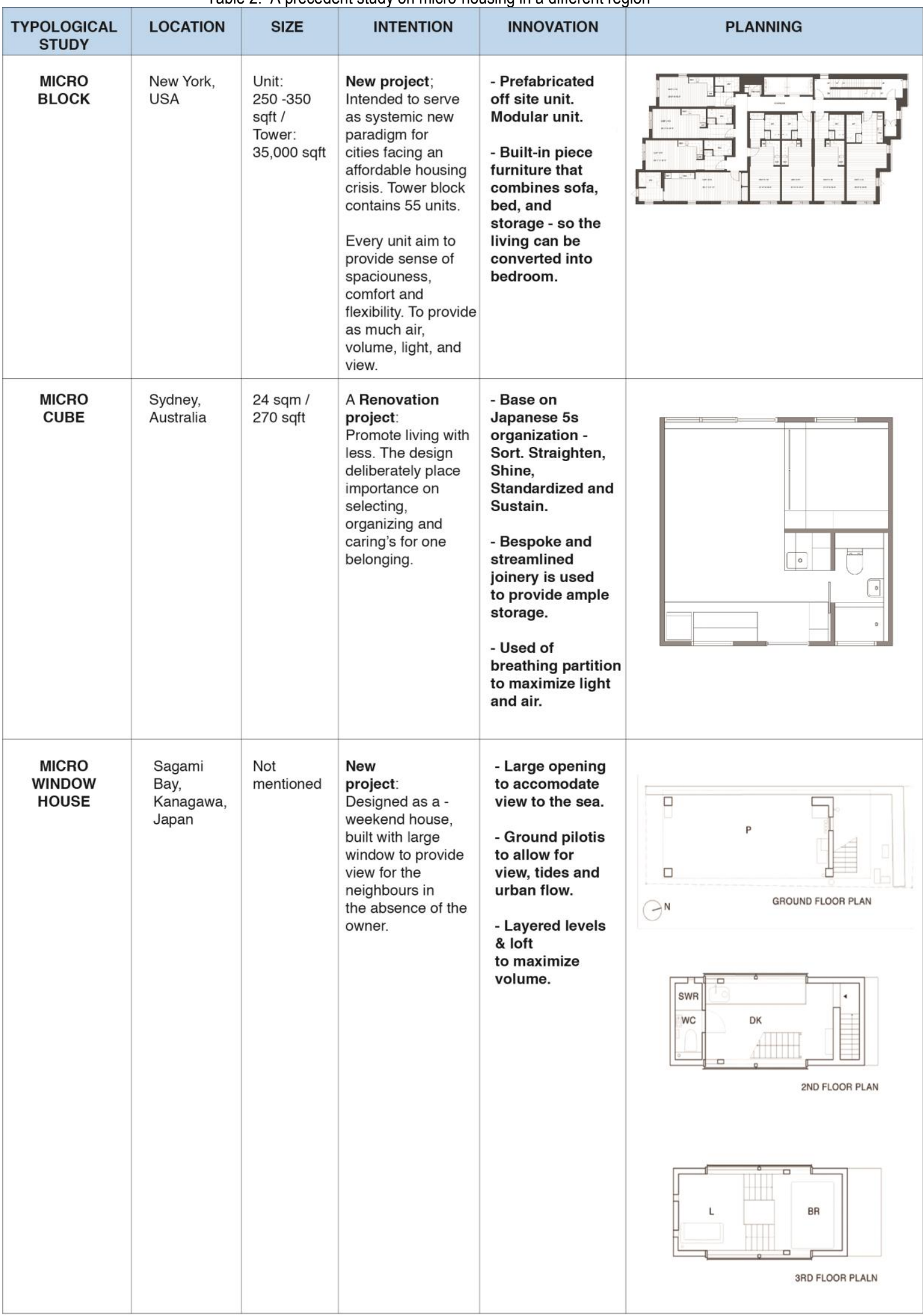

Source: Author 
Table 3: Comparison of the micro-housing typological domain and regional cultural study

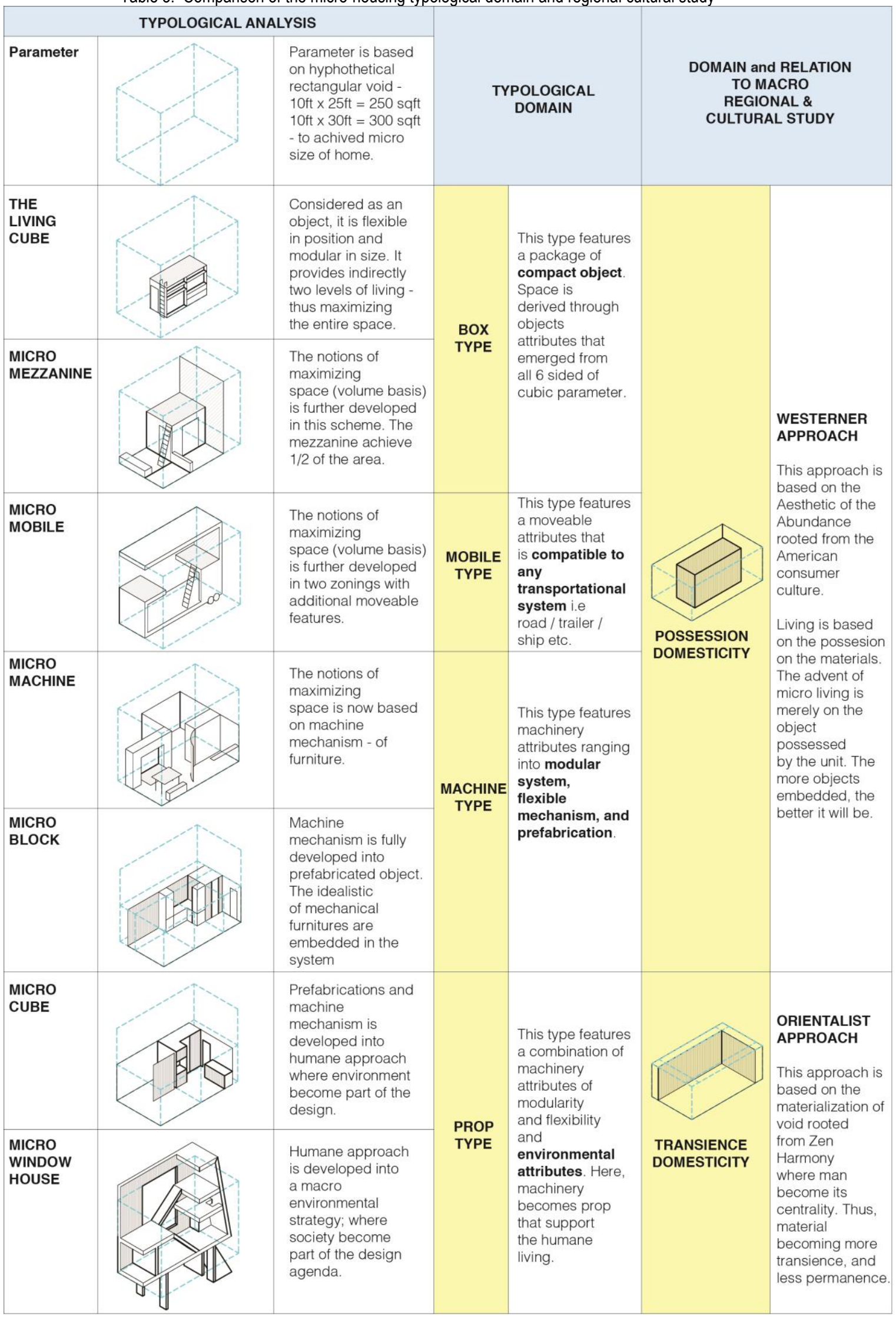


Table 4: Summary of the comparison between the local prototypes and the typological study and the psychological needs of living

\begin{tabular}{|c|c|c|c|c|c|c|}
\hline \multirow{2}{*}{$\begin{array}{c}\text { Local } \\
\text { Approach }\end{array}$} & \multirow{2}{*}{$\begin{array}{l}\text { Main Attributes } \\
\text { (summarized } \\
\text { from Table 1) }\end{array}$} & \multirow{2}{*}{$\begin{array}{c}\text { Comparison with } \\
\text { Typological } \\
\text { Analysis and } \\
\text { Domain }\end{array}$} & \multirow{2}{*}{$\begin{array}{c}\text { Comparison with } \\
\text { Macro Regional } \\
\text { and Cultural } \\
\text { Study }\end{array}$} & \multirow{2}{*}{$\begin{array}{c}\text { New } \\
\text { Approach }\end{array}$} & \multicolumn{2}{|c|}{ Psychological Needs of Living } \\
\hline & & & & & $\begin{array}{c}\text { Human Needs } \\
\text { into Concerns } \\
\text { (personal space, } \\
\text { privacy, } \\
\text { withdrawal, and } \\
\text { territoriality) }\end{array}$ & $\begin{array}{l}\text { Spatial Behaviour } \\
\text { (spatial adaptation, } \\
\text { crowding and the } \\
\text { influence of space) }\end{array}$ \\
\hline $\begin{array}{l}\text { Prototype } \\
\text { 1:Tetawow } \\
\text { e Atelier } \\
\text { and AMC } \\
\text { Architects }\end{array}$ & $\begin{array}{l}\text { - Prefabricated } \\
\text { unit located at } \\
\text { the abundant } \\
\text { car park which } \\
\text { covers two car } \\
\text { parking lots } \\
\text { - Segregation of } \\
\text { space with } \\
\text { sleeping } \\
\text { (private or } \\
\text { confined space) } \\
\text { located above } \\
\text { and semi- } \\
\text { private or semi- } \\
\text { confined space } \\
\text { (indoor } \\
\text { communal area) } \\
\text { below } \\
\text { - Emphasizes on } \\
\text { void and volume } \\
\text { - Outdoor } \\
\text { communal } \\
\text { space } \\
\text { - Towards } \\
\text { sustainable } \\
\text { horizontal/ flat } \\
\text { village }\end{array}$ & $\begin{array}{l}\text { - Possess } \\
\text { similarities with } \\
\text { the prop type with } \\
\text { the optimization of } \\
\text { volume into space } \\
\text { - Environmental } \\
\text { concerns are } \\
\text { given to the act of } \\
\text { openness and } \\
\text { maximizing light, } \\
\text { air, and view } \\
\text { which also posed } \\
\text { resemblance to } \\
\text { micro cube and } \\
\text { micro window } \\
\text { house }\end{array}$ & $\begin{array}{l}\text { - The approach is } \\
\text { more towards } \\
\text { the 'orientalism' } \\
\text { with the } \\
\text { emphasize of } \\
\text { modularity and } \\
\text { centrality of } \\
\text { space } \\
\text { - Not much } \\
\text { emphasis given } \\
\text { to objects }\end{array}$ & $\begin{array}{l}\text { Shared } \\
\text { outdoor } \\
\text { communal } \\
\text { space is } \\
\text { known as } \\
\text { 'kongsi' } \\
\text { which } \\
\text { resembles } \\
\text { the notion of } \\
\text { flat village }\end{array}$ & $\begin{array}{l}\text { - The separation } \\
\text { of space with } \\
\text { sleeping or the } \\
\text { private area } \\
\text { above and } \\
\text { semi-private } \\
\text { space below } \\
\text { defines the } \\
\text { different } \\
\text { functions, } \\
\text { activities, and } \\
\text { role of living. } \\
\text { - The physical } \\
\text { separation of } \\
\text { sleeping } \\
\text { through the } \\
\text { volume of space } \\
\text { marks the } \\
\text { territory of } \\
\text { personal space } \\
\text { and provides a } \\
\text { sense of privacy } \\
\text { and the need for } \\
\text { isolation. }\end{array}$ & $\begin{array}{l}\text { - The limitation of small } \\
\text { space is overcome by } \\
\text { the segregation of } \\
\text { activities in the living } \\
\text { environment and the } \\
\text { maximization of } \\
\text { volume, light, air, and } \\
\text { view } \\
\text { - The confined and } \\
\text { semi-confined space } \\
\text { indicates } \\
\text { personalization of } \\
\text { space mainly for work } \\
\text { and relaxation with } \\
\text { social engagements } \\
\text { conducted outdoors }\end{array}$ \\
\hline $\begin{array}{l}\text { Prototype } \\
\text { S: } \\
\text { Studio } \\
\text { Bikin }\end{array}$ & $\begin{array}{l}\text { - Pavilion as the } \\
\text { concept for } \\
\text { living with } \\
\text { skeletal shell } \\
\text { and insertion of } \\
\text { objects as the } \\
\text { framework } \\
\text { - Prefabricated } \\
\text { house with } \\
\text { flexible layout } \\
\text { and } \\
\text { prefabricated } \\
\text { modular } \\
\text { furniture } \\
\text { - Large outdoor } \\
\text { communal area }\end{array}$ & $\begin{array}{l}\text { - Possess } \\
\text { similarities with } \\
\text { the machine type } \\
\text { which consists of } \\
\text { the micro- } \\
\text { machine and } \\
\text { micro block } \\
\text { - Emphasizes the } \\
\text { use of } \\
\text { prefabricated } \\
\text { modular furniture } \\
\text { that can fold, } \\
\text { move, expand, } \\
\text { elevate and } \\
\text { convert to } \\
\text { different sets of } \\
\text { function and } \\
\text { activities }\end{array}$ & $\begin{array}{l}\text { - Approach is } \\
\text { more towards } \\
\text { the 'westerner' } \\
\text { with objects } \\
\text { embedded } \\
\text { within the space } \\
\text { that define the } \\
\text { micro-living } \\
\text { - Not much } \\
\text { emphasis given } \\
\text { to space }\end{array}$ & $\begin{array}{l}\text { The large } \\
\text { outdoor } \\
\text { communal } \\
\text { area just } \\
\text { outside the } \\
\text { unit which } \\
\text { when } \\
\text { combined } \\
\text { will } \\
\text { resemble a } \\
\text { compact } \\
\text { vertical } \\
\text { village }\end{array}$ & $\begin{array}{l}\text { The act of } \\
\text { personal space, } \\
\text { privacy, } \\
\text { withdrawal, and } \\
\text { territoriality is } \\
\text { achieved through } \\
\text { the modification of } \\
\text { objects within the } \\
\text { framework }\end{array}$ & $\begin{array}{l}\text { - Adaptation of space } \\
\text { through modification } \\
\text { of objects } \\
\text { - Objects determine the } \\
\text { activity and function of } \\
\text { space } \\
\text { - Personalized and } \\
\text { confined and semi- } \\
\text { confined spaces are } \\
\text { within the framework } \\
\text { - The users can } \\
\text { conduct social } \\
\text { activities at the large } \\
\text { communal area } \\
\text { located just outside } \\
\text { the unit }\end{array}$ \\
\hline $\begin{array}{l}\text { Prototype } \\
\text { P: } \\
\text { Perumaha } \\
\text { n Bandar } \\
\text { Jalan } \\
\text { TAR, } \\
\text { DBKL }\end{array}$ & $\begin{array}{l}\text { - A room or } \\
\text { space with } 4 \text { to } \\
6 \text { cubicles } \\
\text { - Prefabricated } \\
\text { modular } \\
\text { wardrobe }\end{array}$ & $\begin{array}{l}\text { Very minimal } \\
\text { similarity seen } \\
\text { which is limited to } \\
\text { the prefabricated } \\
\text { modular wardrobe } \\
\text { - Could possess } \\
\text { similarities with } \\
\text { the box type } \\
\text { through the } \\
\text { modification of } \\
\text { object into a } \\
\text { compact package }\end{array}$ & $\begin{array}{l}\text { - Demarcation of } \\
\text { space through } \\
\text { cubicles } \\
\text { - Minimal } \\
\text { resemblance to } \\
\text { the 'westerner' } \\
\text { approach where } \\
\text { loose and } \\
\text { prefabricated } \\
\text { objects define } \\
\text { the space }\end{array}$ & $\begin{array}{l}\text { Capsule } \\
\text { hotel } \\
\text { concept }\end{array}$ & $\begin{array}{l}\text { The sense of } \\
\text { personal space, } \\
\text { privacy, isolation } \\
\text { and territory is } \\
\text { achieved through } \\
\text { partitions which } \\
\text { create the cubicles }\end{array}$ & $\begin{array}{l}\text { - Not much emphasis } \\
\text { given to building } \\
\text { amenities and } \\
\text { facilities } \\
\text { - Despite its limitation, } \\
\text { the housing is located } \\
\text { in a strategic location } \\
\text { with excellent } \\
\text { infrastructure and } \\
\text { amenities }\end{array}$ \\
\hline
\end{tabular}


Prototype 1 emphasized the separation of space with sleeping or private area located upstairs and an indoor communal or semiprivate area downstairs. This physical separation of space through volume marks the territory of personal space and provides a sense of privacy and the need for isolation among the users. The limitation of space is adapted with the volumetric segregation of activities within the living environment and the maximization of light, air, and view through large openings. In this prototype, one can socialize at the kongsi or outdoor communal area located just outside the enclosed unit.

In prototype 2, the use of modified objects helps to achieve a sense of personal space, privacy, withdrawal, and territoriality. Such objects are prefabricated modular furniture which is flexible and can transform into different functions and activities within the living space. Similar to prototype 1, the users can conduct their social activities at the large communal area located just outside the unit.

Unlike prototype 2, prototype 3 creates the act of personal space, privacy, isolation, and territory through the installation of partitions, which demarcate the boundary of the unit or cubicle. This prototype only provides sleeping and bathing facilities without any consideration of space for social engagement. Despite its limitation in size and facilities, the housing is located in a strategic location and surrounded by excellent infrastructure and amenities.

\subsection{Significant Differences and Similarities between the Prototypes of Local Micro Housing}

The proposal for prototype 1 makes use of the abundant car parks to build micro homes. The spatial layout segregates private and semiprivate space with sleeping or a private area at the upper level and indoor communal area or semi-private area at the lower level. The units can duplicate horizontally to resemble a flat sustainable village. The segregation of space through volume defines the functions and activities in the living environment.

Prototype 2, on the other hand, makes use of prefabricated modular objects to create different functions and activities within an open space. The design also allows the units to stack and overlap to create a compact vertical village.

Prototype 3 significantly differs from prototype 1 and 2 in terms of its function. While prototype 1 and 2 can convert to permanent homes, prototype 3 , is built purely for temporary living as it only offers sleeping and bathing facilities. Despite these differences, there is a distinct similarity between prototype 1 and 2. Outdoor communal areas are designed in both prototypes to serve as a social engagement area among the community.

\subsection{Conclusion and Recommendations}

There have been numerous discussions on affordable housing in Malaysia with emphasis given to micro-homes. While various bodies have made several proposals, the approach towards micro-homes has not been fully visualized, not until recently, where DBKL introduced the micro-housing scheme at Jalan Tuanku Abdul Rahman (TAR), Kuala Lumpur in early 2019. Although this initiative received mixed public reactions, it nevertheless opens up to further study on its similarities with the typological domains of micro-housing from all over the world and its relevance to the locality context.

The data and findings revealed that there are significant similarities between the approach taken by Tetawowe Atelier and AMC Architects and Studio Bikin and the existing typological concept of micro-housing. Although these two schemes emphasized on different typological domains, both proposals not only aimed to solve the housing problems among the B40 community, but it also promotes community living through the sustainable village. In these two proposals, living and psychological needs are extrapolated through function and activities that are defined by physical space and objects.

The Perumahan Bandar Jalan TAR has minimal similarities to the existing typological concept of micro-housing. The approach is based on the concept of Capsule Hotel, where living is temporary and that the proposal takes advantage of the surrounding environment to fulfil its basic amenity needs. While the scheme offers an answer to Max-Neef's existential human needs and Maslow's physiological needs, it lacks consideration of the Max-Neef's axiological human needs and Maslow's other hierarchy of needs.

Although the size of physical space has less effect on existential human needs but at of significant effect on axiological human needs, there is indeed no definition or requirement of small space or small living. According to Jacobsen (2013), a space is too small if it prevents the user from performing or accomplishing their activities. In the case of DBKL, regardless of its limitation in size and temporary status, the axiological human needs must be met, and this can only be achieved through creative spatial optimization and maximizing the values of living.

\section{References}

Daniels.I.M., (2001). The 'Untidy' Japanese House. In Home Possession: Material Culture Behind Closed Doors (pp 202 - 229). New York, NY: Berg

Dober.P, Strannegard.L. (2005). Design, Lifestyle, and Sustainability. Aesthetic Consumption in a World of Abundance. Business Strategy and The Environment. 14, 324 - 336, DOI: $10.1002 / \mathrm{bse} .495$

Foye. C.,(2017). The Relationship Between Size of Living Space and Subjective Well-Being. J Happiness Stud,18:427-461.

Gardiner.S.,(2002). The House - Its Origin and Evolutions. London, UK: Constable \& Robinson Ltd

Garvey.P.,(2001). Organized Disorder: Moving Furniture in Norwegian Homes. In Home Possession: Material Culture Behind Closed Doors (pp 47 - 68). New York, NY: Berg 
Housing in Malaysia, An Issue of Affordability Not Availability, (2018,). Retrived on September 26 from https://www.edgeprop.my/content/1427870/housing-malaysiaissue-affordability-not-availability

Jacobsen.J.B.,(2013). The Needs of Living. Department of Product Design, Norwegian University of Science and Technology.

Lake.R.,(2019). How Millennials are Changing the Housing Market. Retrived on July 3 from https://www.investopedia.com/personal-finance/how-millennials-arechanging-housing-market/

Micro Apartments and Co-Living: The Future of Urban Living, (2018). Retrived September 21 from https://resourcefurniture.com/inspiration/micro-apartments-and-coliving-the-future-of-urban-living/

Microhousing (WUF), (2018). Retrived from http://www.tetawowe.com/mircrohousing-wuf2018.html

Petridou.E., (2001). The Taste of Home. In Home Possession: Material Culture Behind Closed Doors (pp 87 - 104). New York, NY: Berg

Ravenscroft.T. (2019). 10 Micro Homes with Floor Plans That Make The Most of Space. Retrived on March 18 from https://www.dezeen.com/2019/03/18/micro-homefloor-plans-micro-apartment/

Sarip. A.G., Lee.Y.F.,(2015). Exploring The Perception of Lifestyle Housing Development in Malaysia. The Asia Pacific Network for Housing Research (APNHR)

Tan.M.,(2018). The Case For Communal Living. Retrived from https://thinkcity.com.my/the-case-for-communal-living/

Unbuilt Proposal: Micro Housing Within Disused MultyStorey Buildings, (2018). Retrived from https://www.studiobikin.com/ub-micro.php

UNDP, (2016). Support In Developing National B40 Action Plan Using Innovative Bottom Up Approaches. Retrived from

https://www.my.undp.org/content/malaysia/en/home/operations/projects/poverty_reduction/support-in-developing-national-b40-action-plan-using-innovative-.html

Urban Land Institute, (2014). The Macro View on Micro Units. Washington, DC: ULI 